\title{
FENTON AND PHOTO FENTON OXIDATION OF 2-NITROANILINE
}

\author{
Amritha A.S ${ }^{1}$, Manu B ${ }^{2}$ \\ ${ }^{1}$ Research Scholar, NITK, Surathkal Karnataka, India \\ ${ }^{2}$ Assistant Professor, Department of Civil Engineering, NITK Surathkal, Karnataka, India
}

\begin{abstract}
Industries occupy a place of prominence in the Indian economy in view of its massive potential for employment, growth and exports. The aniline derivatives are dye intermediates with wide applications and some of the most extensively used derivatives are 2-nitroaniline, 3-nitroaniline and 4-niroaniline. The disposal of untreated effluents containing these derivate are extremely harmful to the receiving water bodies; new and improved treatment methods are being researched to effectively degrade and remove these harmful compounds present in the industrial effluents before disposal into the environment. In the present study, some of the major toxic aniline derivatives from effluents using Fenton and photo Fenton oxidation methods was carried out. A number of physical methods, chemical methods, and biological methods are available for the treating wastewaters. The degradation of 2-NA in water by Fenton \& Photo-Fenton advanced oxidation process was investigated in this study. The effect of pH (2mM-4mM), initial concentration (0.5mM-2.5mM), $\mathrm{H}_{2} \mathrm{O}_{2}$ concentration $(2 \mathrm{mM}-21.5 \mathrm{mM})$, Fe $\mathrm{e}^{2+}$ concentration $(0.05 \mathrm{mM}$ $0.275 \mathrm{mM})$ on the rate of degradation was investigated. The process was optimized with 2-NA removal efficiency of $89.1 \%$. The photo Fenton oxidation was carried out to increase the removal efficiency of 2-NA. The Kinetic studies were carried out to optimize the reaction time in Fenton and Photo Fenton process.
\end{abstract}

Keywords: 2-Nitroaniline, Fenton oxidation, Photo Fenton oxidation

\section{INTRODUCTION}

An industries role in the Indian economy is very important in terms of employment, growth and exports etc. The industries such as dye, pesticide, pharmaceutical etc are the fast growing sectors. The aniline derivatives are commonly used in these industries as an intermediate. The untreated effluents containing these derivatives are harmful to aquatic life. It is also carcinogenic and mutagenic. The aniline derivatives ate toxic in nature and cause blood, enzyme and nerve damage with cyanosis and danger of suffocation. The aniline and derivatives are found to be major contaminants in many industrial effluents. These hazardous substances readily dissolve in the water up to $3.5 \%$ and thereby increase the risk of possible pollution in wastewater and drinking water sources.

The most commonly used derivatives are 2-Nitroaniline, 3Nitroaniline \& 4-Nitroaniline [11]. These aniline derivatives have dangerous pollutant properties. Aniline has been listed as a probable human carcinogen by U.S. Environmental protection Agency [2]. These aniline derivatives are used as intermediates in the manufacturing process, if around $1000 \mathrm{mg} / \mathrm{L}$ of dye concentration in the dye bath [6] and around $50 \%$ is lost into the effluent [4], hence the concentration of these intermediates may not exceed $300 \mathrm{mg} / \mathrm{L}$.

The wastewater containing these aniline derivatives are the major contaminants in the industrial wastewater or effluent especially in the dye manufacturing units \& pharmaceutical sectors.
The effluent from these industries has been treated by photodecomposition, electrolysis, resin adsorption, ozone oxidation and biodegradation methods. Non-degradable organic pollutants can be treated by several chemical treatment methods. Among the chemical treatment methods listed, the advanced oxidation processes (AOPs) are the most effective methods for the mineralization of the hazardous material [11]. Advanced oxidation processes, which depends on the generation of hydroxyl radical which is an oxidant. Compare to all the advanced oxidation processes, Fenton's and Photo-Fenton's oxidation processes are more promising methods. These methods are cost effective, easy to operate and effective for the degradation of organic pollutants [8].

The advanced oxidation processes have been widely used for the degradation of hazardous materials in the effluents. Studies have been revealed that the Fenton's oxidation processes oxidizing power can be enhanced by the irradiation of UV light i.e. is also called as the photo-Fenton process [10]. The photo-Fenton oxidation process involves the reduction of $\mathrm{Fe}^{3+}$ to $\mathrm{Fe}^{2+}$, so the generation of the additional hydroxyl radical $\left(\mathrm{OH}^{*}\right)$ and continuous regeneration of $\mathrm{Fe}^{2+}$ occurs [12]. These photo-Fenton processes are also powerful in the degradation of the organic pollutants such as aniline, nitrophenols etc [10].

The present study deals with the degradation of 2Nitroaniline and Chemical Oxygen Demand (COD) removal efficiencies by Fenton and Photo-Fenton processes. The effect of $\mathrm{pH}$, hydrogen peroxide concentration $\left(\mathrm{H}_{2} \mathrm{O}_{2}\right)$, iron concentration and initial 2-NA concentration on the degradation by Fenton's process. Further photo -Fenton oxidation studies were carried out with the optimum conditions of the Fenton's process. 


\section{MATERIALS AND METHODS}

\subsection{Chemicals}

2-Nitroaniline (Himedia), was procured from Himedia. Hydrogen peroxide ( $50 \% \mathrm{w} / \mathrm{w})$, Iron (II) sulphate heptahydrate $\left(\mathrm{FeSO}_{4} .7 \mathrm{H}_{2} \mathrm{O}\right)$, Hydrochloric acid $(\mathrm{HCl})$, Sulphuric acid $\left(\mathrm{H}_{2} \mathrm{SO}_{4}\right)$, Sodium Hydroxide $(\mathrm{NaOH})$ were procured from Merck India. The reagents used are of analytical grade and used without purification.

\subsection{Experimental Methods}

All the experiments are conducted in the batch process using a batch reactor. The Photo-Fenton set up consists of a closed chamber consisting a reactor (1L Volume), 8W UV-C Philip lamp which is covered with quartz jacket and connected to the power supply with a magnetic stirrer. The $1000 \mathrm{ml}$ solutions of different initial concentrations were prepared from the $5 \mathrm{mM}$ stock solution of 2-NA and taken in $1 \mathrm{~L}$ for Photo-Fenton and $2 \mathrm{~L}$ for the photo-Fenton process. The $\mathrm{pH}$ of the solution was adjusted to required level using $0.1 \mathrm{mM}$ of $\mathrm{NaOH}$ and $0.1 \mathrm{mM}$ of $\mathrm{H}_{2} \mathrm{SO}_{4}$. An appropriate amount of iron concentration was added to the solution and $\mathrm{pH}$ was adjusted to required level and dosage of the hydrogen peroxide was added to initiate the reaction and solution was mixed thoroughly with a magnetic stirrer. The samples were drawn from the reactor and filtered through $0.45-\mu \mathrm{m}$ Millipore filter membrane for 2-NA, COD and residual hydrogen peroxide analysis.

\subsection{Analytical Methods}

Standard 2-NA solutions were prepared and UV-Vis spectra were recorded using UV-VIS Spectrophotometer (Systronics-2201) from 200-500nm. The $\lambda$ max obtained was $282 \mathrm{~nm}$. The $\mathrm{pH}$ was measured using a digital $\mathrm{pH}$ meter (Lovibond-pH meter). The COD, residual hydrogen peroxide, iron concentrations were measured as per the procedure in the Standard Methods for the Examination of Water and Wastewater (2005). The HPLC analysis was carried out using HPLC (Agilent Binary LC) which has a reverse phase ZORBAX C18 silica column, with diode array detector (DAD) to confirm the results.

\section{RESULTS AND DISCUSSION}

\subsection{Effect of $\mathbf{p H}$}

The effect of $\mathrm{pH}$ on the 2-NA \& COD removal efficiencies were carried out. Fig 1 shows the removal efficiencies of 2 NA \& COD. The $\mathrm{pH}$ was varied in the range of 2-4 at an interval of 0.5 . The maximum 2-NA removal and COD removal were observed to be $89.1 \%$ and $73 \%$ respectively at $\mathrm{pH}$ 2.5. The maximum 2-NA removal efficiency is at 2.5 may be due to the fact that, the formation of a greater number of $\mathrm{Fe}(\mathrm{OH})^{+}$which was more active than the $\mathrm{Fe}^{2+}$ in Fenton's oxidation process [1]. As the $\mathrm{pH}$ increases above 2.5 , the removal efficiency decreases, that may be because of the fact, the production of $\mathrm{OH}$ radical by the decomposition of hydrogen peroxide. When the $\mathrm{pH}$ is less than 2.5, the oxidation of the hydrogen peroxide and $\mathrm{Fe}^{2+}$ because of the formation of the water by the reaction of $\mathrm{OH}$ radical and $\mathrm{H}^{+}$ion [5].

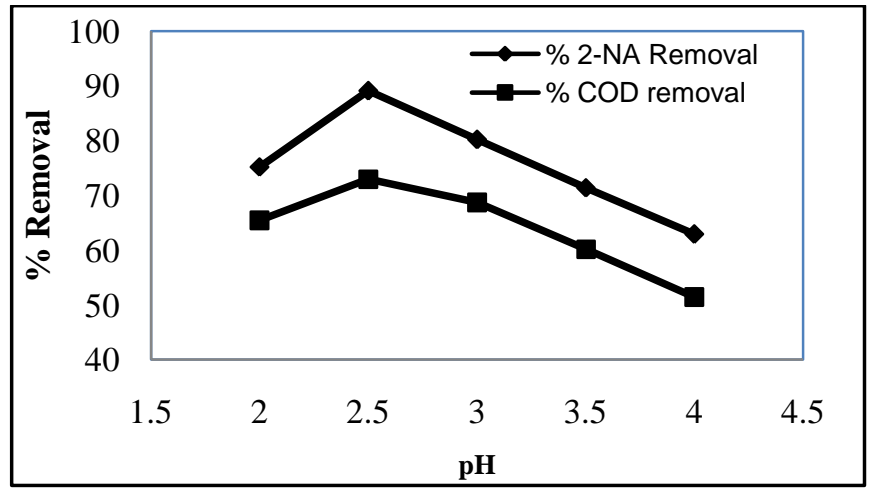

Fig 1: Effect of $\mathrm{pH}$ on removal of 4-nitroaniline

\subsection{Effect of $\mathrm{H}_{2} \mathrm{O}_{2}$ and $\mathrm{Fe}^{2+}$ Concentration}

The effect of concentration on the removal efficiency is carried out by keeping the iron concentration constant and by varying the $\mathrm{H}_{2} \mathrm{O}_{2}$ concentration in the range of $2 \mathrm{mM}$ to $21.5 \mathrm{mM}$ and at a constant $\mathrm{pH}$ of 2.5. The maximum 2-NA removal efficiency and COD removal obtained was $89.1 \%$ and $73 \%$ for $0.5 \mathrm{mM}$ of the initial concentration of the 2-NA. It is observed from the experiments that, the as the concentration of the hydrogen peroxide increases the removal efficiency increases till it reached the critical concentration and after that, it starts decreasing.

The iron concentration is optimized by keeping the previously optimized hydrogen peroxide as constant and by varying the iron concentration in the range of $0.025 \mathrm{mM}$ $0.275 \mathrm{mM}$ for the range of $2-\mathrm{NA}$ from $0.5 \mathrm{mM}-2.5 \mathrm{mM}$. It was observed that, as iron concentration increases 2-NA removal increases it may be due to the increased production of $\mathrm{OH}$ radical [13]. Further increase in the iron concentration, the removal efficiency decreases and it may be due to the inhibition of ferrous ion [8].

\subsection{Effect of initial concentration}

The experiments were conducted at different initial concentrations ranging from $0.5 \mathrm{mM}-2.5 \mathrm{mM}$ to evaluate the effect of initial concentration of 2-NA. The removal efficiencies decreased as the initial concentration of the 2NA increased from $0.5 \mathrm{mM}$ to the higher concentration. Table 1 shows the removal efficiency of 2-NA by varying initial concentrations. The decrease in the removal efficiency may be due to the formation of the intermediate compound during the oxidation process, further, it may block the availability of $\mathrm{OH}$ radical for the oxidation process [7], [8].

Table 1: Optimum dosages obtained during Fenton's oxidation of 2-Nitroaniline

\begin{tabular}{|l|l|l|l|l|}
\hline $\begin{array}{l}2-\mathrm{NA} \\
\begin{array}{l}\text { Concentraton } \\
(\mathrm{mM})\end{array}\end{array}$ & $\begin{array}{l}\mathrm{H}_{2} \mathrm{O}_{2} \\
\text { dosage } \\
(\mathrm{mM})\end{array}$ & $\begin{array}{l}\mathrm{Fe} \\
\text { dosage } \\
(\mathrm{mM})\end{array}$ & $\begin{array}{l}\text { 2-NA } \\
\text { removal } \\
(\%)\end{array}$ & $\begin{array}{l}\text { COD } \\
\text { removal } \\
(\%)\end{array}$ \\
\hline 0.5 & 3.5 & 0.05 & 89.1 & 73 \\
\hline 1.0 & 7.5 & 0.1 & 88.3 & 69.1 \\
\hline 1.5 & 12 & 0.15 & 86.4 & 65.4 \\
\hline 2.0 & 16.5 & 0.2 & 81.4 & 61.6 \\
\hline 2.5 & 21 & 0.25 & 78 & 58.2 \\
\hline
\end{tabular}




\subsection{Photo- Fenton Oxidation Process}

Photo -Fenton oxidation experiments were conducted at optimum $\mathrm{pH}$, optimized dosages of hydrogen peroxide and iron. Fig 2 represents the removal efficiencies of the 2-NA at varying initial concentration. The removal efficiencies are slightly higher than the Fenton's oxidation process. The removal efficiencies decreased with increase in the initial concentration of the 2-NA and this may be because of the fact that, photons which are available may decrease with increase in the concentration leads to the decrease in the $\mathrm{OH}$ radicals in the solution [3]. After analysing the results, it is observed that removal efficiencies obtained in the photoFenton process are higher compare to the Fenton's oxidation process. The more removal efficiency may be due to that, the production of $\mathrm{OH}$ radical due to the regeneration of $\mathrm{Fe}^{2+}$ ion, which degrades more 2-NA and the intermediated formed [8].

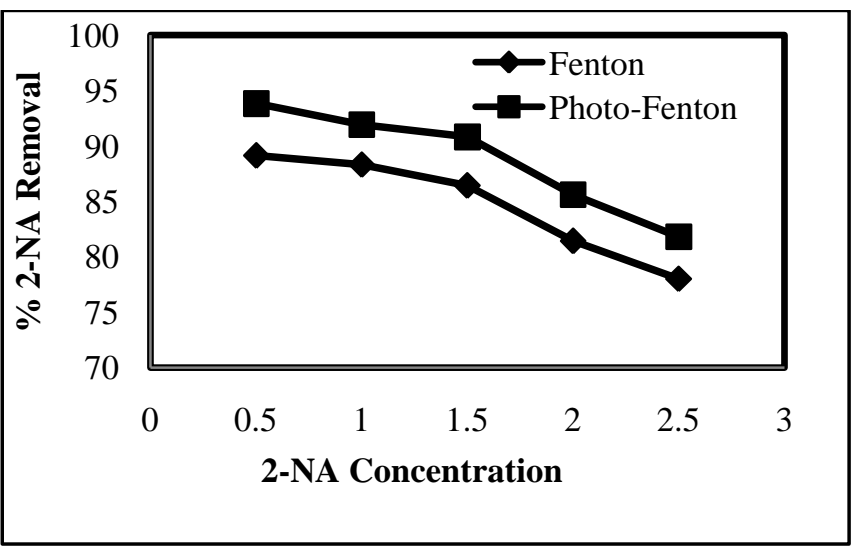

Fig 2: 2-Nitroaniline removal by Fenton \& Photo-Fenton

\section{CONCLUSIONS}

The UV light assisted photo-Fenton oxidation process is more efficient compare to the Fenton's oxidation process. The optimum $\mathrm{pH}$ for the removal of $2-\mathrm{NA}$ is 2.5 . The maximum 2-NA removal efficiency of $93.8 \%$ was observed for $0.5 \mathrm{mM}$ of 2-NA concentration and the optimum hydrogen peroxide concentration of $3.5 \mathrm{mM}$ and $0.05 \mathrm{mM}$ of iron concentration was used. The removal efficiency is slightly nearly $4 \%$ higher as compare to the Fenton's oxidation process.

\section{REFERENCES}

[1] Badawy MI, Ali MEM. 2006 Fenton's peroxidation and coagulation processes for the treatment of combined industrial and domestic wastewater. J. of Hazardous materials, 2006; B136: 961-966.

[2] Dvorak L, Lederer T, Jirku V, Masak J, Noval L. Removal of aniline, cyanides and diphenylguanidine from industrial wastewater using a full-scale moving bed biofilm reactor. Process Biochemistry, 2014; 49: 102-109.

[3] Feng J, Hu X, Yue PL, Zhu HY, Lu GQ. Decolourization and mineralization of reactive red HE-3B by heterogeneous photo-Fenton reaction. Water resources ,2003; 37: 3776-3784.
[4] Khan TA, Sing VV, Kumar D. 2004 Removal of some basic dyes from artificial textile wastewater by adsorption on Akash Kinari Coal. J. of Scientific and Industrial Research, 2004; 63 (4): 355-364.

[5] Lucas MS, Peres JA. Decolourization of Azo dye Reactive Black 5 by Fenton and Photo Fenton Oxidation. Dyes and Pigments, 2006; 71: 236-244.

[6] Manu B, Chaudhari S. Anaerobic decolourization of simulated textile wastewater containing azo dyes. Bioresource Technology, 2002; 82: 225-231.

[7] Manu B, Mahamood. Degradation Kinetics of Diclofenac in water by Fenton's oxidation. J. of Sustainable Energy and Environment, 2012; 3: 173-176.

[8] Manu B, Mahamood. Enhanced degradation of paracetamol by UV-C supported Photo-Fenton process over Fenton oxidation. Water Science and Technology, 2011; 64 (12): 2433-2438.

[9] Standard Methods for the Examination of Water and Wastewater 2005 21st edn, American Public Health Association/ American Water Works Association/Water Environment Federation, Washington, DC, USA.

[10] Sun JH, Sun SP, Fan MH, Guo HQ, Lee YF, Sun RX. Oxidative decomposition of p-nitroaniline in water by solar photo-Fenton advanced oxidation process. J. of Hazardous Materials, 2008; 153:187-193.

[11] Sun JH, Sun SP, Fan M, Guo HQ, Qiao LP, Sun RX. 2007 A kinetic study on the degradation of p-nitroaniline by Fenton oxidation process. J. of Hazardous Materials, 2007; 148: 172-177.

[12] Sun Y, Pingnatello JJ. Photochemical reactions involved in the total mineralization od $2,4 \mathrm{D}$ by $\mathrm{Fe}^{3+} / \mathrm{H}_{2} \mathrm{O}_{2} /$ UV. Environmental Science \& Technology, 1993; 27: 304310.

[13] Yilmaz T, Aygun A, Nas B. Removal of COD and colour from young municipal landfill leachate by Fenton process. Environmental Technology, 2010; 31(14): 16351640 . 